\title{
Growth and nickel uptake by serpentine and non-serpentine populations of Fimbristylis ovata (Cyperaceae) from Sri Lanka
}

\author{
P. K. D. Chathuranga ${ }^{\mathrm{A}, \mathrm{B}}$, S. K. A. T. Dharmasena ${ }^{\mathrm{A}}$, N. Rajakaruna ${ }^{\mathrm{C}, \mathrm{D}}$ and M. C. M. Iqbal ${ }^{\mathrm{A}, \mathrm{E}}$ \\ A Institute of Fundamental Studies, Hanthana Road, Kandy, Sri Lanka. \\ ${ }^{B}$ Postgraduate Institute of Science, University of Peradeniya, Peradeniya, Sri Lanka. \\ ${ }^{\mathrm{C} C}$ College of the Atlantic, 105 Eden Street, Bar Harbor, ME 04609, USA. \\ DUnit for Environmental Sciences and Management, North-West University, Potchefstroom, South Africa. \\ ${ }^{\mathrm{E}}$ Corresponding author. Email: mcmif2003@yahoo.com
}

\begin{abstract}
Compared with serpentine floras of Southeast Asia, the serpentine vegetation of Sri Lanka is impoverished in regard to serpentine endemics and nickel hyperaccumulators. All species so far documented from the serpentine outcrops of Sri Lanka also have non-serpentine populations; it is unclear whether the serpentine populations are physiologically distinct and deserve ecotypic recognition. We conducted a preliminary study to examine whether serpentine and non-serpentine populations of Fimbristylis ovata represent locally adapted ecotypes by investigating their growth and potential for nickel uptake and tolerance under greenhouse conditions. Although both populations of $F$. ovata showed a similar growth pattern in serpentine soil during short-term exposure (21 days), the non-serpentine population was unable to survive in serpentine soil under long-term exposure (4 months). Both populations were able to uptake nickel from serpentine soil during short-term exposure (21 days). The serpentine population, however, translocated significantly more nickel from its roots to shoots (translocation factor 0.43) than the non-serpentine population (translocation factor 0.29). Our preliminary investigations suggest that the serpentine and non-serpentine populations of $F$. ovata may be locally adapted to their respective soils. However, additional studies are required to determine whether the populations deserve ecotypic recognition.
\end{abstract}

Additional keywords: ecotypic differentiation, edaphic tolerance, geobotany, ion uptake, nickel tolerance, population differentiation, restoration ecology, serpentine ecology.

\section{Introduction}

Serpentine soil is derived from a range of ultramafic rocks (Moores 2011) and contains elevated concentrations of metals such as nickel (Ni), chromium $(\mathrm{Cr})$, cadmium $(\mathrm{Cd})$ and cobalt $(\mathrm{Co})$ and is characterised by a calcium : magnesium $(\mathrm{Ca}: \mathrm{Mg})$ ratio of $<1$, low essential nutrients including nitrogen $(\mathrm{N})$, phosphorus $(\mathrm{P})$ and potassium $(\mathrm{K})$, moisture stress, soil instability, high soil surface temperature, and a generally high $\mathrm{pH}$ (O'Dell and Rajakaruna 2011). Serpentine soils are found in many parts of the world and they harbour distinct plant communities consisting of a high proportion of rare and endemic species (Alexander et al. 2007; Rajakaruna et al. 2009; Harrison and Rajakaruna 2011) as well as locally adapted populations, i.e. ecotypes (O'Dell and Rajakaruna 2011). In Sri Lanka, ultramafic rocks occur along a Precambrian suture zone at the boundary of the Vijayan and Highland Series, metamorphic remnants of two ancient tectonic plates (Dissanayake and Van Riel 1978; Munasinghe and Dissanayake 1979, 1980; Dissanayake 1982; Ranasinghe 1987). The geochemistry of these outcrops, particularly of Ussangoda along the southern coast, has received much attention in recent years (Tennakoon et al. 2007; Rajapaksha et al. 2012,
2013; Hewawasam et al. 2014; Vithanage et al. 2014). Knowledge of ultramafic geology and soils is fundamental to biological and ecological studies and the geochemical research has laid a strong foundation for interdisciplinary studies examining the soil-biota relations of the serpentine outcrops of Sri Lanka. The floristics of the serpentine outcrops of Sri Lanka, especially of Ussangoda, have also received some attention (Brooks 1987; Senevirathne et al. 2000; Rajakaruna and Bohm 2002; Rajakaruna et al. 2002; Rajakaruna and Baker 2004; Weerasinghe and Iqbal 2011); however, ecological, evolutionary and applied research on serpentine plants and their associated biota is minimal. Several plant species found at Ussangoda are able to uptake high levels of heavy metals (Rajakaruna and Bohm 2002; Weerasinghe and Iqbal 2011), including levels of Ni considered as hyperaccumulation (van der Ent et al.2013a; Pollard et al.2014). Notable in this regard are Evolvulus alsinoides (Convolvulaceae; Senevirathne et al. 2000; Rajakaruna and Bohm 2002; Rajakaruna and Baker 2004; MCM Iqbal, YAS Samithri, DSA Wijesundera, unpubl. data), Hybanthus enneaspermus (Violaceae; Senevirathne et al. 2000; Rajakaruna and Bohm 2002; Rajakaruna and Baker 2004; Weerasinghe and Iqbal 2011), Flacourtia indica (Flacourtiaceae; 
MCM Iqbal, YAS Samithri, DSA Wijesundera, unpubl. data), Olax imbricata (Olacaceae; MCM Iqbal, YAS Samithri, DSA Wijesundera, unpubl. data), Toddalia asiatica (Rutaceae; MCM Iqbal, YAS Samithri, DSA Wijesundera, unpubl. data), Euphorbia heterophylla (Euphorbiaceae; MCM Iqbal, YAS Samithri, DSA Wijesundera, unpubl. data), Vernonia cinerea (Asteraceae; MCM Iqbal, YAS Samithri, DSA Wijesundera, unpubl. data) and Crotalaria sp. (Fabaceae; Senevirathne et al. 2000; Rajakaruna and Bohm 2002; Rajakaruna and Baker 2004). Ni-hyperaccumulating plants from serpentine soil, such as those documented from Ussangoda, may be ideal candidates for the phytoextraction of heavy metals (Reeves et al. 1999; Rajakaruna and Baker 2004; Berazaín et al.2007) and for the restoration (via phytostabilisation) of metal-enriched sites degraded from mining activities (O'Dell and Claassen 2011). The majority of species currently utilised for phytoextraction and phytomining of Ni come from Mediterranean climates (Gall and Rajakaruna 2013); therefore, there is a need for research on tropical Ni-tolerant and Ni-hyperaccumulating plants (Reeves 2003; Fernando et al. 2014; Jaffré et al. 2013; van der Ent et al. 2013b) for restoration, revegetation and phytomining operations in tropical climes.

Sri Lanka has greater biodiversity per unit area than any other country in Asia (Myers 1990; Baldwin 1991; Gunawardene et al. 2007); however, the serpentine outcrops of the island do not appear to harbour any serpentine endemics (Brooks 1987; Rajakaruna and Baker 2004). It is unclear why an island as rich in biodiversity, particularly plant endemism (Gunawardene et al. 2007), should harbour such an apparently impoverished serpentine flora. In comparison to serpentine floras of Southeast Asia (Fernando and Rodda 2013; van der Ent and Wood 2013; Fernando et al. 2014; van der Ent and Vanijajiva 2014), the serpentine flora of Sri Lanka is impoverished with regard to both number of species and percentage endemism (Rajakaruna and Baker 2004). Factors that may contribute to this apparent anomaly may be limited sampling as well as collections that are often restricted to those species that could be identified by using floral or reproductive features; rare or endemic taxa may be overlooked if they are not in flower or fruit at the time of collection. Additionally, limited sampling could also hinder observations of morphological or phenological features that might indicate genotypic differences between serpentine and non-serpentine populations. So far, all species documented from serpentine outcrops in Sri Lanka are found both on and off serpentine soil, seemingly indifferent to substrate differences. For those species showing any intraspecific variation with respect to morphological or physiological features, including flowering time differences, common garden and reciprocal transplant experiments (Wright and Stanton 2011) should be undertaken to determine whether populations are locally adapted to their substrate (i.e. whether there is evidence for ecotypic differentiation). Ecotypes are a critical stage in the speciation process (O'Dell and Rajakaruna 2011) and the recognition of such population differentiation is critical for evolutionary studies (Harrison and Rajakaruna 2011) as well as for the selection of populations to be used in site remediation or restoration (Gall and Rajakaruna 2013). Rajakaruna and Bohm (2002) stated that several serpentine-associated taxa in Sri Lanka might benefit from further observations and additional greenhouse studies to determine whether the serpentine populations are genetically distinct and are worthy of ecotypic recognition. These taxa include several Niaccumulating and -hyperaccumulating species, particularly Hybanthus enneaspermus, Evolvulus alsinoides, Crotalaria sp., Desmodium triflorum (Fabaceae) and Fimbristylis sp. (Cyperaceae), all showing recognisable phenotypic differences between serpentine and non-serpentine populations.

Fimbristylis ovata is found widely distributed in Sri Lanka. Rajakaruna and Bohm (2002) and Weerasinghe and Iqbal (2011) reported dry leaf tissue $\mathrm{Ni}$ concentrations of $371.5 \mu \mathrm{g} \mathrm{g}^{-1}$ and $220 \mu \mathrm{g} \mathrm{g}^{-1}$, respectively, for $F$. ovata plants from Ussangoda, where it is one of the dominant herbaceous ground-cover species. Field observations have pointed to differences in plant size and growth habit among plants found on and off serpentine soils and it is unclear whether these populations represent ecotypes, locally adapted to their distinct substrates. In the present study, we examine whether there is evidence for physiological differentiation within this species in response to serpentine soils, and compare the growth and potential for uptake and accumulation of Ni between serpentine and non-serpentine populations under greenhouse conditions.

\section{Materials and methods}

\section{Chemicals and instrumentation}

Analytical grade chemicals and reagents were used in all experiments. Deionised water obtained from an ion-exchange water apparatus (Advantec Model Aquarius GS-20, Tokyo, Japan) was used to prepare all aqueous solutions. The $\mathrm{pH}$ of solutions was measured by a $\mathrm{pH}$ meter (Thermo Russell Model RL060P, Thermo Electron Corp., Singapore). The plants were digested using a microwave digester (Milestone Model START D, Italy). Ni was analysed by atomic absorption spectrophotometer (AAS; GBC 933 M, Melbourne, Vic., Australia) at the wavelength of $232.0 \mathrm{~nm}$, using airacetylene flame.

\section{Sampling of plants}

Fifty $F$. ovata plants were randomly collected from throughout each of the study sites at Ussangoda (serpentine habitat; coordinates $606^{\prime} 01^{\prime \prime} \mathrm{N}, 8059^{\prime} 06^{\prime \prime} \mathrm{E}$ ) and Pallekele (nonserpentine habitat; coordinates $716^{\prime} 48^{\prime \prime} \mathrm{N}, 8042^{\prime} 09^{\prime \prime} \mathrm{E}$ ) and their taxonomy was verified at the National Herbarium, Royal Botanic Garden, Peradeniya, Sri Lanka. Of the collected plants, only those of similar size and fresh weight were selected for the experiments. Roots and shoots of all the plants were washed thoroughly with deionised water before they were introduced into the growth media.

\section{Preparation of growth media}

Serpentine soil samples were collected from different locations of the Ussangoda serpentine site, from within areas where the plants were collected, and were bulked and homogenised. Subsequently, the soil was passed through a sieve with aperture size $2.0 \mathrm{~mm}$ and used as the Ni-enriched soil treatment for subsequent experiments. The non-serpentine soil consisted of $2: 1: 1$ garden soil, compost and sand. 
Effect of serpentine soil on the growth of $\mathrm{F}$. ovata

Five $F$. ovata plants of each population were potted individually in five plastic pots, each consisting of $1 \mathrm{~kg}$ of serpentine and non-serpentine soil, respectively (five plants five pots two treatments). Pots were kept in a greenhouse at $28 \quad 30 \mathrm{C}$ and 64-68\% humidity during the experiment. Plants were exposed to natural light consisting of approximately $12 \mathrm{~h}$ of day and $12 \mathrm{~h}$ of night. Plants were watered four times per week. Plants were harvested after 4 months and their growth was assessed under the two treatments.

\section{Uptake of Ni from serpentine soil by serpentine and non-serpentine populations of $\mathrm{F}$. ovata}

Fimbristylis ovata plants were grown under conditions similar to the study described above to assess $\mathrm{Ni}$ uptake by the two populations. The experimental design was identical to that previously described. Plants were harvested after 21 days, and washed thoroughly in running water, followed by $10 \mathrm{mmol} \mathrm{L} 1$ solution of disodium salt of EDTA and deionised water. Plants were dried at $60 \mathrm{C}$ for 3 days, and subsequently separated into shoots and roots and weighed. Plant materials were digested with $9 \mathrm{~mL}$ of $\mathrm{HNO}_{3} 69 \%$ in a microwave digester and analysed by AAS (Varian Model AA 280FS) to determine the Ni content in plant tissues.

\section{Statistical analysis}

The data were analysed by one-way ANOVA, using the computer software Minitab (released 14.03, Minitab, State College, PA, USA) to determine the significance of differences between the pairs of means. The treatment means were compared using Tukey's 95\% simultaneous confidence-interval test. The differences were statistically significant when $P<0.05$.

\section{Results}

Effect of serpentine soil on the growth of $\mathrm{F}$. ovata

Fimbristylis ovata plants of both populations grew well in serpentine soil during the short-term experimental period of 21 days. Significant differences were not observed in morphology, growth habit or dry weights of the two populations (Fig. 1). However, a significant difference was observed in the growth and dry weight, when the two populations grew in serpentine soil for a longer period of 4 months (Fig. 1). The serpentine population accumulated a significantly higher biomass on serpentine soil than did the non-serpentine population at the time of harvest.

\section{Uptake of Ni from serpentine soil by serpentine and non-serpentine populations of $\mathrm{F}$. ovata}

The two populations did not show a significant difference in $\mathrm{Ni}$ concentration in their shoots. Ni concentration of the roots of the serpentine population was significantly $(P<0.05)$ lower than that of the non-serpentine population (Fig. 2). However, 30\% of total Ni taken up by the plant was accumulated in the shoots of the serpentine population whereas shoots of the non-serpentine population accumulated only $22 \%$. Accumulation of $\mathrm{Ni}$ in shoots of both populations was lower than that in their roots (Fig. 2).

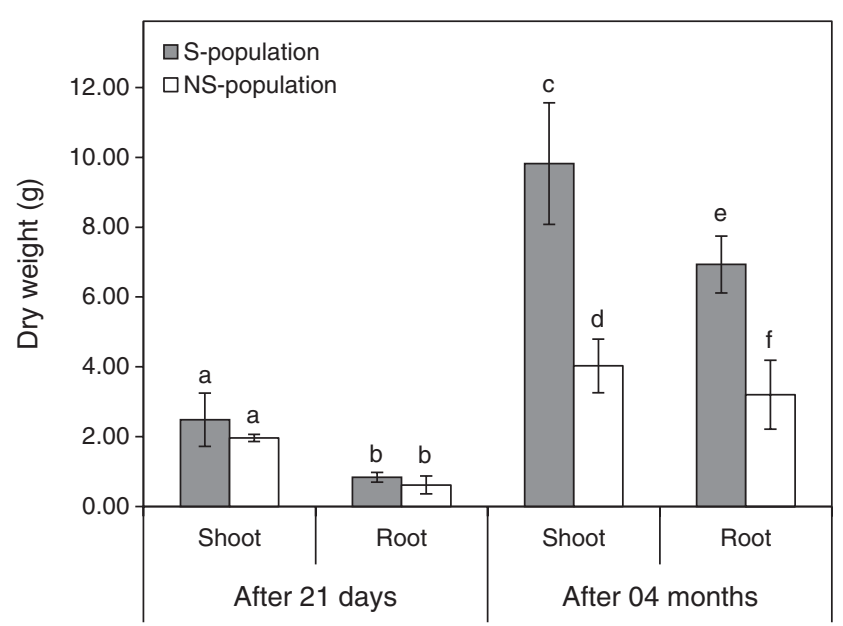

Fig. 1. Dry weight of shoots and roots of Fimbristylis ovata grown in serpentine soil and harvested after 21 days or 4 months. Bars indicate mean s.d., where $n=5$. Different letters indicate statistically significant differences between treatments (at $P=0.05$ ), based on Tukey's $95 \%$ simultaneous confidence intervals test $(\mathrm{S}=$ serpentine, $\mathrm{NS}=$ non-serpentine $)$.

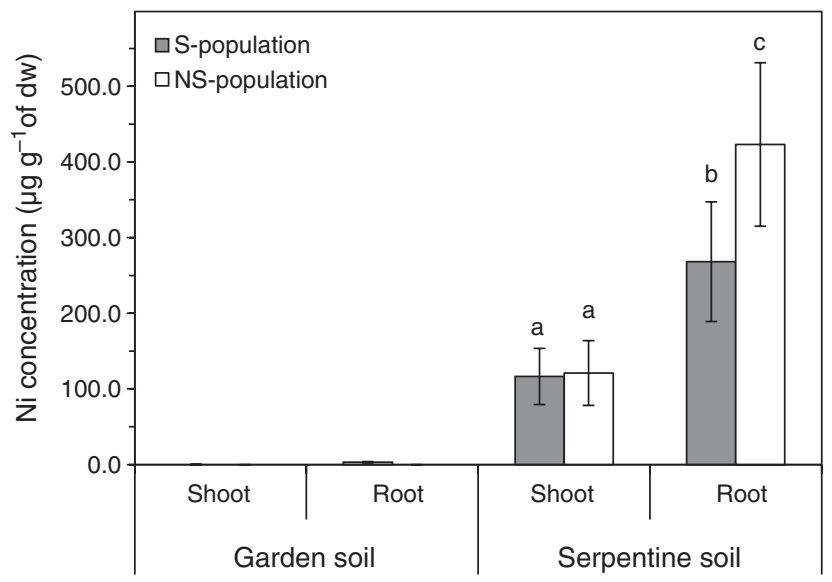

Fig. 2. Concentration of nickel in the shoots and roots of Fimbristylis ovata from Ussangoda (serpentine) and Pallekele (non-serpentine) habitats, grown in serpentine soil over 21 days. Bars indicate mean s.d., where $n=5$. Different letters indicate statistically significant differences between treatments (at $P=0.05$ ), based on Tukey's $95 \%$ simultaneous confidence intervals test $(\mathrm{dw}=$ dry weight, $\mathrm{S}=$ serpentine, $\mathrm{NS}=$ non-serpentine $)$.

The translocation factor (TF) for $\mathrm{Ni}$ in $F$. ovata plants was calculated using the following equation:

$$
\mathrm{TF}=C_{\text {shoots }} / C_{\text {roots }},
$$

$C_{\text {shoots }}$ is the Ni concentration in shoots $\left(\mu \mathrm{gg}^{-1}\right)$ and $C_{\text {roots }}$ is the metal concentration in roots $\left(\mu \mathrm{gg}^{-1}\right)$. The $\mathrm{TF}$ values for serpentine and non-serpentine populations were 0.43 and 0.28 , respectively, indicating that the serpentine population translocated more $\mathrm{Ni}$ from their roots to shoots than did the non-serpentine population.

\section{Discussion}

Our study provides preliminary evidence for physiological differentiation in response to serpentine soils between 
serpentine and non-serpentine populations of $F$. ovata. Although both populations were able to perform similarly in serpentine soils in the short term (21 days), there was a significant difference in both above- and below-ground biomass in the serpentine population growing in serpentine soils under longterm (4 months) exposure, compared with the non-serpentine population. The lower biomass seen in the non-serpentine population when grown in serpentine soils may not be due only to $\mathrm{Ni}$ and other metal toxicity, but also to the deficiency of essential nutrients such as $\mathrm{N}, \mathrm{P}, \mathrm{K}$, and $\mathrm{Ca}$ and moisture stress often characterising serpentine soil (Rajakaruna and Baker 2004; Alexander et al. 2007) or changes in the beneficial microbiota in the two soils (Southworth et al. 2014). Decreases in both above- and below-ground biomass when exposed to serpentine soils can have a significant influence on competitive ability (Moore and Elmendorf 2011) as well as reproductive fitness (Ghasemi et al. 2014). Such intraspecific variation leading to local adaptation (i.e. ecotypic differentiation) has been frequently cited (O'Dell and Rajakaruna 2011) for species found on and off of serpentine soils. Additional studies utilising common-garden, reciprocal-transplant and genetic approaches (Wright and Stanton 2011) are now needed to demonstrate ecotypic differentiation in $F$. ovata found on serpentine and non-serpentine soils in Sri Lanka.

Both $F$. ovata populations showed similar concentrations of $\mathrm{Ni}$ in the shoots after a 21-day exposure; however, the roots of the non-serpentine population accumulated more $\mathrm{Ni}$ than did the roots of the serpentine population. This is indicated by the translocation-factor (TF) differences that we observed for $\mathrm{Ni}$, with the serpentine population showing nearly a two-fold increase in Ni translocation to shoot compared with the non-serpentine population. This is a typical response seen among species and ecotypes adapted to ionically extreme soils, where the locally adapted taxon is able to translocate more of the 'toxic' ions into shoots than is the taxon found on 'normal' soils (Rajakaruna et al. 2003; O'Dell and Rajakaruna 2011), suggesting internal mechanisms in place for metal tolerance (Gall and Rajakaruna 2013). Our investigation on the $\mathrm{Ni}$ tolerance of $F$. ovata suggests that the serpentine populations may be suitable for phytostabilising degraded serpentine and other metal-enriched settings in Sri Lanka (Vithanage et al. 2014) and in other parts of the species' native range. Its relatively fast growth rates, extensive above-ground material, fibrous root mass, and ease of cultivation can contribute to effective phytostabilisation (Mendez and Maier 2008; Alkorta et al. 2010; Neilson and Rajakaruna 2012) of degraded habitats enriched with $\mathrm{Ni}$. Our study also points to the importance of using the proper genotype (i.e. serpentine-tolerant individuals) for success in any such restoration effort. Sri Lanka has many examples of soils polluted by heavy metals (Ileperuma 2000; Rajakaruna et al. 2006) and the use of metal-tolerant populations of native species for the remediation of these soils is preferable to the importation of exotic species (Gall and Rajakaruna 2013).

Sri Lanka's serpentine outcrops and their flora have received relatively little attention partly because they do not harbour any endemic species. However, our study suggests that these outcrops may be home to previously under-appreciated ecotypes worthy of study and conservation. Therefore, it is critical that Sri Lanka's serpentine outcrops receive regional and national recognition and are declared as ecologically sensitive sites (i.e. geoecological preserves) to be set aside for future investigations. Without proper management, conservation and research, these unique habitats and their physiologically distinct biota are extremely vulnerable. Rinorea bengalensis (Wall.) O.K. (Violaceae) offers an example of why such efforts are urgently needed. Brooks and Wither $(1977 a, 1977 b)$ conducted a survey of herbarium specimens from the entire range of this species, encompassing Sri Lanka, the Malay Archipelago, New Guinea, the Solomon Islands and Queensland, Australia, and found that Ni hyperaccumulation is widespread in this plant. The level of $\mathrm{Ni}$ found in the herbarium specimen from Sri Lanka was in excess of $10000 \mathrm{ppm}$ (i.e. 10-fold the minimum required to be a $\mathrm{Ni}$ hyperaccumulator; van der Ent et al. 2013a). This high concentration indicates that the specimen tested was collected from a serpentine site, the locality indicated on a map presented by Brooks and Wither (1977a) suggesting a collection in the central part of the island (see fig. 1 in Rajakaruna and Baker 2004). This species was not encountered in the field exploration of Rajakaruna and Bohm (2002) and is now presumed extinct in Sri Lanka (Ministry of Environment and Renewable Energy 2012).

Our preliminary study on $F$. ovata points to the need for detailed floristic surveys to be undertaken at all of the serpentine outcrops in Sri Lanka (Rajakaruna and Bohm 2002; Vithanage et al. 2014) to document any species showing unusual physiological behaviours with respect to ion accumulation or exhibiting distinct vegetative or reproductive traits, relative to their conspecifics on non-serpentine soils. Once such taxa are documented, they should be carefully evaluated under laboratory and greenhouse conditions for any differences in their physiology and reproductive biology. Additionally, population genetic studies can be conducted to determine whether serpentine populations are genetically distinct from those found on non-serpentine soils. Only with such careful examination can we conclude whether the serpentine flora of Sri Lanka is impoverished (Brooks 1987; Rajakaruna and Baker 2004) or whether many of the bodenvag (i.e. soil indifferent; sensu Kruckeberg 1984) species found on serpentine outcrops of Sri Lanka should deserve ecotypic or taxonomic recognition.

\section{Acknowledgements}

The authors thank the National Research Council of Sri Lanka for financial support (research grant 06-29), Ms Shirani Perera and Mr R. B. Hapukotuwa for technical assistance, and two anonymous reviewers and Dr Antony van der Ent for providing critical comments and suggestions for improving the manuscript.

\section{References}

AlexanderEB, Coleman RG, Keeler-Wolfe T, Harrison SP (2007) ‘Serpentine geoecology of western North America: geology, soils, and vegetation.' (Oxford University Press: New York)

Alkorta I, Becerril JM, Garbisu C (2010) Phytostabilization of metal contaminated soils. Reviews on Environmental Health 25, 135-146. doi:10.1515/REVEH.2010.25.2.135

Baldwin MF (Ed.) (1991) Natural resources of Sri Lanka. Conditions and trends. A report prepared for the natural resources, energy and science authority of Sri Lanka. Keels Business Systems Ltd, Colombo, Sri Lanka. 
Berazaín R, de la Fuente V, Rufo L, Rodríguez N, Amils R, Díez-Garretas B, Sánchez-Mata D, Asensi A (2007) Nickel localization in tissues of different hyperaccumulator species of Euphorbiaceae from ultramafic areas of Cuba. Plant and Soil 293, 99-106. doi:10.1007/s11104-007-9227-3

Brooks RR (1987) 'Serpentine and its vegetation: a multi-disciplinary approach.' (Dioscorides Press: Portland, OR)

Brooks RR, Wither ED (1977a) Nickel hyperaccumulation by Rinorea bengalensis (Wall.) O.K. Journal of Geochemical Exploration 7, 295-300. doi:10.1016/0375-6742(77)90085-1

Brooks RR, Wither ED (1977b) Cobalt and nickel in Rinorea species. Plant and Soil 47, 707-712. doi:10.1007/BF00011041

Dissanayake CB (1982) The geology and geochemistry of the Uda Walawe serpentinite. Sri Lanka. Journal National Science Council Sri Lanka 10, 13-34.

Dissanayake CB, Van Riel BJ (1978) The petrology and geochemistry of a recently discovered nickeliferous serpentinite from Sri Lanka. Journal of the Geological Society of India 19, 464-471.

Fernando ES, Rodda M (2013) Marsdenia purpurella (Apocynaceae, Asclepiadoideae), a new species from the Philippines. Gardens' Bulletin Singapore 65, 143-148.

Fernando ES, Quimado MO, Doronila AI (2014) Rinorea niccolifera (Violaceae), a new, nickel-hyperaccumulating species from Luzon Island, Philippines. PhytoKeys 37, 1-13. doi:10.3897/phytokeys.37.7136

Gall JE, Rajakaruna N (2013) The physiology, functional genomics, and applied ecology of heavy metal-tolerant Brassicaceae. In 'Brassicaceae'. (Ed. M Lang) pp. 121-148. (Nova: Hauppauge, NY)

Ghasemi R, Chavoshi ZZ, Boyd RS, Rajakaruna N (2014) A preliminary study of the role of nickel in enhancing flowering of the nickel hyperaccumulating plant Alyssum inflatum Nyár. (Brassicaceae). South African Journal of Botany 92, 47-52. doi:10.1016/j.sajb.2014.01.015

Gunawardene NR, Daniels DAE, Gunatilleke IAUN, Gunatilleke CVS, Karunakaran PV, Nayak GK, Prasad S, Puyravaud P, Ramesh BR, Subramanian KA, Vasanthy G (2007) A brief overview of the western ghats: Sri Lanka biodiversity hotspot. Current Science 93, 1567-1572.

Harrison SP, Rajakaruna N (2011) 'Serpentine: the evolution and ecology of a model system.' (University of California Press: Berkeley, CA)

Hewawasam T, Fernando GWAR, Priyashantha D (2014) Geo-vegetation mapping and soil geochemical characteristics of the Indikolapelessa serpentinite outcrop, southern Sri Lanka. Journal of Earth Science 25, 152-168. doi:10.1007/s12583-014-0409-7

Ileperuma OA (2000) Environmental pollution in Sri Lanka: a review. Journal of the National Science Foundation of Sri Lanka 28, 301-325.

Jaffré T, Pillon Y, Thomine S, Merlot S (2013) The metal hyperaccumulators from New Caledonia can broaden our understanding of nickel accumulation in plants. Frontiers in Plant Science 4, 279. doi: $10.3389 /$ fpls.2013.00279

Kruckeberg AR (1984) 'California serpentines: flora, vegetation, geology, soils, and management problems.' University of California publications in botany 78. (University of California Press: Berkeley, CA)

Mendez MO, Maier RM (2008) Phytostabilization of mine tailings in arid and semiarid environments-an emerging remediation technology. Environmental Health Perspectives 116, 278-283. doi:10.1289/ehp. 10608

Ministry of Environment and Renewable Energy (2012) 'The national red list 2012 of Sri Lanka; conservation status of the fauna and flora.' (Ministry of Environment: Columbo, Sri Lanka) viii +476 pp. Availiable at http:// www.environmentmin.gov.lk/web/index.php?option=com_content\&view $=$ article\&id=175\&Itemid=291\&lang=en. [24 March 2014]

Moore KA, Elmendorf SC (2011) Plant competition and facilitation in systems with strong environmental gradients. In 'Serpentine: the evolution and ecology of a model system'. (Eds SP Harrison, N Rajakaruna) pp. 223-236. (University of California Press: Berkeley, CA)
Moores EM (2011) Serpentinites and other ultramafic rocks. Why they are important for earth's history and possibly for its future. In 'Serpentine: the evolution and ecology of a model system'. (Eds SP Harrison, N Rajakaruna) pp. 3-28. (University of California Press: Berkeley, CA)

Munasinghe T, Dissanayake CB (1979) Is the highland-eastern Vijayan boundary in Sri Lanka a possible mineralized belt? Economic Geology 74, 1495-1496. doi:10.2113/gsecongeo.74.6.1495

Munasinghe T, Dissanayake CB (1980) Is the highland eastern Vijayan boundary in Sri Lanka a possible mineralized belt? - A reply. Economic Geology 75, 775-777. doi:10.2113/gsecongeo.75.5.775

Myers N (1990) The biodiversity challenge: expanded hot-spots analysis. The Environmentalist 10, 243-256. doi:10.1007/BF02239720

Neilson S, Rajakaruna N (2012) Roles of rhizospheric processes and plant physiology in applied phytoremediation of contaminated soils using Brassica oilseeds. In 'The plant family Brassicaceae: contribution towards phytoremediation'. Environmental pollution book series, vol. 21. (Eds NA Anjum, I Ahmad, ME Pereira, AC Duarte, S Umar, NA Khan) pp. 313-330. (Springer: Dordrecht, The Netherlands)

O'Dell RE, Claassen VP (2011) Restoration and revegetation of harsh soils. In 'Serpentine: the evolution and ecology of a model system'. (Eds SP Harrison, N Rajakaruna) pp. 383-413. (University of California Press: Berkeley, CA)

O'Dell RE, Rajakaruna N (2011) Intraspecific variation, adaptation, and evolution. In 'Serpentine: the evolution and ecology of a model system'. (Eds SP Harrison, N Rajakaruna) pp. 97-137. (University of California Press: Berkeley, CA)

Pollard AJ, Reeves RD, Baker AJ (2014) Facultative hyperaccumulation of heavy metals and metalloids. Plant Science 217, 218, 8-17. doi:10.1016/j.plantsci.2013.11.011

Rajakaruna N, Baker AJM (2004) Serpentine: a model habitat for botanical research in Sri Lanka. Ceylon Journal of Science (Biological Sciences) 32, 1-19.

Rajakaruna N, Bohm BA (2002) Serpentine and its vegetation: a preliminary study from Sri Lanka. Journal of Applied Botany 76, 20-28.

Rajakaruna N, Harris CS, Towers GHN (2002) Antimicrobial activity of plants collected from serpentine outcrops in Sri Lanka. Pharmaceutical Biology 40, 235-244.

Rajakaruna N, Siddiqi MY, Whitton J, Bohm BA, Glass AD (2003) Differential responses to $\mathrm{Na}^{+} / \mathrm{K}^{+}$and $\mathrm{Ca}^{2+} / \mathrm{Mg}^{2+}$ in two edaphic races of the Lasthenia californica (Asteraceae) complex: a case for parallel evolution of physiological traits. New Phytologist 157, 93-103. doi:10.1046/j.1469-8137.2003.00648.x

Rajakaruna N, Tompkins KM, Pavicevic PG (2006) Phytoremediation: an affordable green technology for the clean-up of metal contaminated sites in Sri Lanka. Ceylon Journal of Science 35, 25-39.

Rajakaruna N, Harris TB, Alexander EB (2009) Serpentine geoecology of eastern North America: a review. Rhodora 111, 21-108.

Rajapaksha AU, Vithanage M, Oze C, Bandara WMAT, Weerasooriya R (2012) Nickel and manganese release in serpentine soil from the Ussangoda ultramafic complex, Sri Lanka. Geoderma 189-190, 1-9.

Rajapaksha AU, Vithanage M, Ok YS, Oze C (2013) Cr(VI) formation related to $\mathrm{Cr}(\mathrm{III})$-muscovite and birnessite interactions in ultramafic environments. Environmental Science and Technology 47, 9722-9729. doi:10.1021/es4015025

Ranasinghe NS (1987) 'Serpentinites associated with the Precambrian of Sri Lanka.' Geological Society of Sri Lanka special publication no. 3. (Geological Survey Department: Colombo, Sri Lanka)

Reeves RD (2003) Tropical hyperaccumulators of metals and their potential for phytoextraction. Plant and Soil 249, 57-65. doi:10.1023/A:1022572517197

Reeves RD, Baker AJM, Borhidi A, Berazain R (1999) Nickel hyperaccumulation in the serpentine flora of Cuba. Annals of Botany 83, 29-38. doi:10.1006/anbo.1998.0786 
Senevirathne AS, Nandadasa HG, Fernando WS, Sanjeevani HHVM, Rajapakshe RLHR (2000) The serpentine vegetation of Ussangoda (Hambantota District) and nickel accumulating plant species. In 'Proceedings of the sixth annual forestry and environmental symposium, Kandy, Sri Lanka'. (Ed. H Amarasekera). (Dept. of Environment and Forestry, University of Sri Jayawardenapura: Sri Lanka). Available at http://journals.sjp.ac.lk/index.php/fesympo/article/ view/1430

Southworth D, Tackaberry LE, Massicotte HB (2014) Mycorrhizal ecology on serpentine soils. Plant Ecology and Diversity 7, 445-455. doi:10.1080/17550874.2013.848950

Tennakoon K, Senevirathna MKI, Kehelpannala KVW (2007) Extraction of pure metallic nickel from ores and plants at Ussangoda, Sri Lanka. Journal of the National Science Foundation Sri Lanka 35, 245-250.

van der Ent A, Vanijajiva O (2014) Gynura tambuyukonensis (Asteraceae), an obligate ultramafic and endemic species from Mount Tambuyukon (Kinabalu Park), Sabah (Malaysia). Phytotaxa 158, 291-296.

van der Ent A, Wood JJ (2013) Orchids of extreme serpentinite (Ultramafic) habitats in Kinabalu Park. Malesian Orchid Journal 12, $39-54$. van der Ent A, Baker AM, Reeves R, Pollard AJ, Schat H (2013a) Hyperaccumulators of metal and metalloid trace elements: facts and fiction. Plant and Soil 362, 319-334. doi:10.1007/s11104-012-1287-3

van Der Ent A, Baker AJM, Van Balgooy MMJ, Tjoa A (2013b) Ultramafic nickel laterites in Indonesia (Sulawesi, Halmahera): mining, nickel hyperaccumulators and opportunities for phytomining. Journal of Geochemical Exploration 128, 72-79. doi:10.1016/j.gexplo.2013.01.009

Vithanage M, Rajapaksha AU, Oze C, Rajakaruna N, Dissanayake CB (2014) Metal release from serpentine soils in Sri Lanka. Environmental Monitoring and Assessment 186, 3415-3429. doi:10.1007/s10661-014-3626-8

Weerasinghe HAS, Iqbal MCM (2011) Plant diversity and soil characteristics of the Ussangoda serpentine site. Journal of the National Science Foundation of Sri Lanka 39, 355-363. doi:10.4038/jnsfsr.v39i4.3884

Wright JW, Stanton ML (2011) Local adaptation in heterogeneous landscapes: reciprocal transplant experiments and beyond. In 'Serpentine: the evolution and ecology of a model system'. (Eds SP Harrison, N Rajakaruna) pp. 155-179. (University of California Press: Berkeley, CA) 